\title{
EFEKTIVITAS E-SAMSAT, PAJAK PROGRESIF DAN KUALITAS PELAYANAN TERHADAP KEPATUHAN WAJIB PAJAK KENDARAAN BERMOTOR
}

\author{
al Gusti Ayu Mas Rosita Dewi, bKadek Wulandari Laksmi P \\ Fakultas Ekonomi dan Bisnis, Universitas Pendidikan Nasional (Undiknas) Denpasar \\ aigustiayumasrositadewi@g.mail.com
}

\begin{abstract}
The Effectiveness of E-Samsat, Progressive Tax and Quality of Service in Improving Vehicle Tax Compliance. The more the economy develops, the more needs and welfare of the community will increase, thus increasing the implementation of government tasks in development and services to improve the welfare of the community. As time goes on, Indonesian State revenues increasingly depend on revenues from the tax sector. Tax is the most dominant source of revenue and is one of the government's efforts to realize national development. Motor Vehicle Tax is one of the highest tax contributors in Regional Original Income and each year the number of motor vehicles continues to increase. Therefore the government issued an E-SAMSAT innovation as a means of convenience for taxpayers to pay taxes, and imposed a progressive tax to control the level of congestion that was generated by the high use of motorized vehicles, as well as the quality of services provided to taxpayers to feel comfortable when performing their obligations. This study has a focus on problems, namely the effectiveness of E-SAMSAT, progressive tax and service quality on motor vehicle taxpayer compliance in 2018 , whether by implementing the system and the regulation can improve motor vehicle taxpayer compliance. The results of the study found that the effectiveness of the use of e-Samsat can affect motor vehicle tax compliance in the UPT. Regional Revenue Agency of the Province of Bali in the City of Denpasar. With the implementation of the Progressive Tax at the UPT. The Regional Revenue Agency of Bali Province in Denpasar City greatly influences the level of compulsory tax compliance of motorized vehicles. The level of compliance of motor vehicle taxpayers declined but was not very meaningful. Service quality at UPT. The Provincial Revenue Agency of Bali in Denpasar City strives to be improved in accordance with the rules and SOPs of regulation, by providing the best attitude, excellent service to improve service quality. The application of eSamsat and Progressive Tax and the quality of service can improve motor vehicle taxpayer compliance.
\end{abstract}

Keywords: E-samsat, progressive tax, service quality, motor vehicle taxpayer compliance

\section{PENDAHULUAN}

Pajak merupakan sumber penerimaan yang paling dominan dan merupakan salah satu upaya pemerintah untuk mewujudkan pembangunan nasional. Potensi yang ada disetiap daerah diharapkan mampu dimaksimalkan dengan baik, agar pemerintah daerah dapat meningkatkan pendapatan daerahnya, memiliki Pendapatan Asli Daerah (PAD) yang maksimal merupakan keinginan setiap daerah. Sumber Pendapatan Asli Daerah (PAD) yang banyak berkontribusi pada setiap Daerah adalah Pajak Daerah, salah satu jenis Pajak Daerah adalah Pajak Kendaraan Bermotor. Pajak kendaraan bermotor merupakan salah satu sumber pendapatan daerah yang digunakan dala anggaran otonomi daerah. Instansi yang menangani pembayaran Pajak Kendaraan Bermotor adalah Badan Pendapatan Daerah melalui Unit Pelayanan Teknis (UPT) Sistem Administrasi Manunggal dibawah Satu Atap (SAMSAT). 
Menurut Peraturan Daerah Provinsi Bali No. 1 tahun 2011, Pajak Kendaraan Bermotor (PKB) adalah pajak atas kepemilikan ataupun penguasaan kendaraan bermotor. Wajib PKB yaitu orang pribadi, badan ataupun instansi pemerintahan yang mempunyai kendaraan bermotor. Dasar untuk pengenaan PKB dapat dihitung dengan perkalian dari dua unsur pokok yaitu nilai jual kendaraan bermotor dan bobot yang menjelaskan secara relatif kadar kerusakan jalan ataupun pencemaran lingkungan yang diakibatkan oleh penggunaan kendaraan bermotor.

Untuk memudahkan wajib pajak membayar pajak kendaraan bermotor dan sebagai inovasi pengembangan teknologi informasi, pemerintah mengembangkan Electronic SAMSAT atau E-SAMSAT. E-SAMSAT dapat memudahkan wajib pajak membayar pajak dengan sistem online. Pengembangan inovasi ini terus ditingkat oleh pemerintah dan semakin diminati oleh wajib pajak, terutama bagi wajib pajak yang tidak mempunyai waktu yang cukup karena mempunyai waktu yang fleksibel untuk membayar kewajibannya. Pembayaran pajak dapat dilakukan dimana saja dan kapan saja sesuai dengan tempat pembayaran yang tertera di aplikasi dan batas tanggal masa berlaku pajak kendaraan bermotor.

Peningkatan kendaraan bermotor pribadi tidak dapat diantisipasi karena kapasitas jalan untuk kendaraan pribadi tidak sesuai dengan kapasitas kendaraan bermotor, oleh karena kemacetan tidak dapat dihindarkan. Salah satu upaya pemerintah dalam menanggulangi kemacetan yaitu dengan menerapkan pajak progresif yang bertujuan untuk mengurangi angka kemacetan. Pajak progresif merupakan pajak yang dikenakan kepada seseorang yang memiliki kendaraan bermotor lebih dari 1 unit. Kendaraan tersebut bisa berupa mobil atau motor. Semakin banyak kendaraan pribadi yang dimiliki seseorang maka semakin besar pajak kendaraan bermotor yang harus dibayarkan.

Kualitas pelayanan merupakan sesuatu yang sangat penting untuk meningkatkan kualitas, kenyamanan dan kinerja suatu perusahaan. Palda dan Hanousek (2002) menjelaskan bahwa rasa senang maupun puas mengenai pelayanan yang diperoleh dari pemerintah bisa memberikan motivasi dan kepatuhan untuk wajib pajak yang pada akhirnya dapat membuat penerimaan kas negara menjadi meningkat. Maka dari itu kualitas pelayanan yang diberikan oleh pemerintah inilah yang harus selalu diperbaiki dan tingkatkan.

Jumlah kendaraan yang terdaftar di Provinsi Bali pada tahun 2016 yaitu sebanyak 3.703.042. Kota Denpasar menempati urutan pertama dengan jumlah 1.243.145 kendaraan bermotor. Selama periode lima tahun terakhir, jumlah wajib pajak yang telah membayar pajak dan yang menunggak di Kantor Bersama SAMSAT Kota Denpasar dari tahun 2012-2016 dapat dilihat pada Tabel 1 berikut.

\section{Tabel 1}

Wajib Pajak yang Telah Melaksanakan Kewajiban Perpajakkannya dan juga yang Masih Menunggak di Kantor Bersama SAMSAT Kota Denpasar Pada Tahun 2012-2016

\begin{tabular}{|c|c|c|c|}
\hline Tahun & $\begin{array}{c}\text { Unit yang } \\
\text { Terealisasi }\end{array}$ & $\begin{array}{c}\text { Unit yang } \\
\text { Menunggak }\end{array}$ & $\begin{array}{c}\text { Persentase } \\
\text { Unit yang } \\
\text { Menunggak } \\
(\%)\end{array}$ \\
\hline 2012 & 775.292 & 462 & 0,06 \\
\hline 2013 & 938.149 & 836 & 0,089 \\
\hline 2014 & 756.730 & 313 & 0,041 \\
\hline 2015 & 765.726 & 62 & 0,008 \\
\hline 2016 & 747.407 & 66 & 0,009 \\
\hline
\end{tabular}

Tabel 1 diatas menunjukkan bahwa jumlah wajib PKB yang menunggak dari tahun 2012 ke 2013 mengalami peningkatan yang signifikan sebesar 80,95 persen (374 unit). Pada tahun 2014 dan 2015 wajib pajak yang menunggak mengalami penurunan yaitu sebesar 62,56 persen (523 unit) dan 80,19 persen (251 unit). Namun tahun 2016 jumlah yang menunggak kembali mengalami peningkatan yang tidak signifikan yaitu sebesar 6,54 persen (4 unit). (Luh Ayu Gustiari \& Herkulanus Bambang Suprasto, 2018). 


\section{Pokok Permasalahan}

Penelitian ini memiliki fokus permasalah yaitu efektivitas E-SAMSAT, pajak progresif dan kualitas pelayanan terhadap kepatuhan wajib pajak kendaraan bermotor pada tahun 2018 , apakah dengan menerapkan sistem dan peraturan tersebut dapat meningkatkan kepatuhan wajib pajak kendaraan bermotor.

\section{KAJIAN LITERATUR}

\section{Pajak}

Pengertian pajak menurut Undang-Undang No. 28 Tahun 2007 Tentang Perubahan Ketiga Undang-Undang No. 6 Tahun 1983 tentang Ketentuan Umum dan Tata Cara Perpajakan adalah :

"Pajak adalah kontribusi Wajib Pajak kepada Negara yang terutang oleh orang pribadi atau badan yang bersifat memaksa berdasarkan Undang-Undang, dengan tidak mendapatkan imbalan secara langsung dan digunakan untuk keperluan Negara bagi sebesar-besarnya kemakmuran rakyat."

Menurut Feldmann dalam Wirawan $(2014 ; 6)$ pengertian pajak adalah sebagai berikut: "Pajak adalah prestasi yang dipaksakan sepihak oleh terutang kepada penguasa, (menurut norma-norma yang ditetapkan secara umum), tanpa adanya kostra-prestasi, dan sematamata digunakan untuk menutup pengeluaran-pengeluaran umum."

\section{Theory Task Technology Fit (TTF)}

Theory Task Technology Fit (TTF) dikembangkan oleh Goodhue dan Thompson. (Goodhue and Thompson 1995) mengemukakan bahwa TTF menjelaskan sejauh mana teknologi membantu individu untuk mengerjakan tugasnya, atau lebih spesifiknya TTF adalah hubungan antara kebutuhan tugas, kemampuan individu dan fungsionalitas teknologi. Teknologi merupakan alat individu untuk menyelesaikan tugas mereka (Goodhue and Thompson 1995). Dalam konteks sistem informasi, teknologi terkait dengan sistem komputer dan penggunaan jasa pendukung yang memberikan panduan pengguna dalam penyelesaian tugas.

\section{Theory of Planned Behavior}

Theory of Planned Behavior (TPB) adalah pengembangan dari Theory Reasoned Action (TRA). Menurut Ajzen (1991) dalam (Anggraini and Waluyo 2014), TPB merupakan teori yang menjelaskan bahwa perilaku seseorang sangat dipengaruhi oleh niat dari individu itu sendiri terhadap suatu perilaku (behavioral intention). Niat tersebut dipengaruhi oleh 3 (tiga) faktor, antara lain: behavioral belief, yaitu keyakinan individu atas hasil yang diperoleh dari suatu perilaku. Kedua normatif belief, yaitu keyakinan individu atas harapan normatif individu lain, di mana harapan normatif tersebut membuat individu menjadi ingin mewujudkannya. Ketiga, Control belief merupakan keyakinan seseorang akan adanya hal-hal yang dapat menghambat atau mendukung perilakunya.

\section{METODE}

\section{Lokasi Penelitian}

Lokasi penelitian dilakukan di UPT. Badan Pendapatan Daerah Provinsi Bali di Kota Denpasar yang beralamat di JI. Kapten Tantular No. 1 Renon, Denpasar, Bali.

\section{Jenis Data}

Jenis data yang digunakan dalam penelitian ini berupa data kualitatif yang bersifat deskriptif dan data penerimaan yang didapat dari lokasi penelitian 


\section{Sumber Data}

Data yang digunakan dalam penelitian ini adalah data primer yang diperoleh langsung dari lokasi penelitian dan data sekunder yang telah diolah dan diperoleh melalui berbagai sumber bacaan yang tersedia.

\section{Informan Penelitian}

Informasi penelitian ini merupakan pihak-pihak yang dapat memberikan informasi mengenai situasi dan kondisi latar belakang penyelenggaraan e-Samsat, pajak progresif dan kualitas pelayanan, sehingga data yang dihasilkan akurat, seperti Kasi PKB dan beberapa staff yang terkait. Peneliti juga akan memilih informan dari masyarakat yaitu dengan sengaja memilih secara acak beberapa wajib pajak kendaraan bermotor yang sedang mengurus atau yang sudah selesai dalam melaksanakan kewajiban pajak kendaraan bermotor.

\section{Instrumen Penelitian}

Sebuah penelitian membutuhkan beberapa instrumen untuk mendapatkan data yang valid. Pertama yang dilakukan dalam penelitian ini adalah dengan peneliti terjun langsung ke lapangan yaitu melakukan pengamatan ke UPT. Badan Pendapatan Daerah Provinsi Bali di Kota Denpasar untuk memperoleh data dari informan yang terkait seperti wajib pajak kendaraan bermotor dan juga pihak-pihak dari UPT. Badan Pendapatan Daerah Provinsi Bali di Kota yang berwenang dalam e-Samsat, pajak progresif dan kualitas pelayanan. Selain itu dalam penelitian ini peneliti menggunakan alat bantu pengumpulan data yaitu pedoman wawancara, alat perekam berupa handphone dan buku catatan lapangan yang digunakan untuk melengkapi data penelitian serta dapat menunjang keabsahan hasil penelitian.

\section{Teknik Pengumpulan Data}

1. Studi Dokumentasi yaitu melihat atau menganalisis dokumen-dokumen yang berhubungan dengan permasalahan yang akan diteliti dan dibuat.

2. Wawancara yaitu teknik pengumpulan data dengan mengadakan tanya jawab secara langsung dengan beberapa wajib pajak kendaraan bermotor dan pihak-pihak dari UPT. Badan Pendapatan Daerah Provinsi Bali di Kota Denpasar, dengan memberikan pertanyaan-pertanyaan terkait dengan permasalahan yang diteliti.

\section{Teknik Analisis Data}

\section{Model Interaksi Analisis Data}

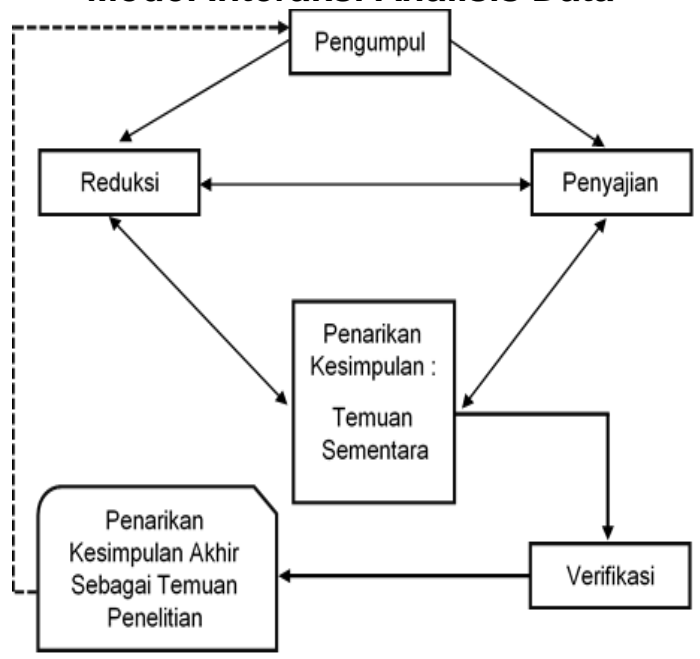

\section{Reduksi Data}

Reduksi data merupakan kegiatan merangkum catatan-catatan lapangan dengan melakukan pemilihan atau memilah-milah data yang akan digunakan, pengeditan, menyederhanakan dan mengelompokkan data-data kasar yang muncul dari catatan di lapangan. 


\section{Display Data}

Display data berguna untuk melihat gambaran keseluruhan hasil penelitian baik yang berbentuk matrik atau pengkodean, dari hasil reduksi data dan display data itulah selanjutnya peneliti dapat menarik kesimpulan data memverifikasikannya sehingga menjadi data yang bermakna.

2. Kesimpulan dan Verifikasi

Untuk menetapkan kesimpulan yang lebih beralasan dan tidak lagi berbentuk kesimpulan yang coba-coba, maka verifikasi dilakukan sepanjang penelitian berlangsung, sehingga menjamin signifikasi atau kebermaknaan hasil penelitian ini.

\section{Teknik Pemeriksaan Keabsahan Data}

Dalam penelitian ini untuk menguji keabsahan data yaitu menggunakan:

1. Triangulasi sumber digunakan untuk membandingkan dan mengecek ulang data hasil wawancara yang diperoleh dari informasi pihak-pihak terkait.

2. Triangulasi teknik digunakan peneliti pada saat membandingkan hasil wawancara antara satu informan dengan informasi yang sama namun dengan cara berbeda.

\section{HASIL DAN PEMBAHASAN}

\section{E-Samsat}

Berdasarkan hasil wawancara yang dilakukan pada tanggal 1 November 2018 dengan I Wayan Agus Bagiarta, S.ST selaku Kasi PKB menjelaskan bahwa sejak diluncurkannya sistem e-Samsat pada bulan September 2017 ini masyarakat sangat merespon dan sangat terbantu, terutama bagi wajib pajak yang tidak mempunyai cukup waktu untuk membayar pajak kendaraan bermotor, dan tanpa harus menunggu lama di kantor Samsat sehingga sangat mengefisienkan waktu. Setelah diluncurkan hingga Oktober 2018 kurang lebih sudah 6.000 pengguna e-Samsat, tentu saja jumlah tersebut akan terus meningkat, jadi dengan diterapkannya e-Samsat ini dapat meningkatkan kepatuhan wajib Pajak Kendaraan Bermotor. Sebelum menggunakan e-Samsat, wajib pajak terlebih dahulu melaporkan pajak progresif sehingga kendaraan yang dimiliki oleh wajib pajak sudah terdaftar di pajak progresif dan sistem. Jika tidak melaporkan pajak progresif pada sistem e-Samsat akan terlihat jika kendaraan yang dimiliki belum terdaftar, jadi wajib pajak tidak bisa menggunakan aplikasi e-Samsat.

Jika wajib pajak sudah melakukan pendaftaran pada aplikasi dan melakukan pembayaran, maka wajib pajak datang ke kantor Samsat sesuai dengan domisili kendaraan bermotor untuk melakukan pengesahan STNK dan SKPD dengan membawa persyaratan yaitu : 1) Bukti Pembayaran, 2) STNK asli, 3) KTP asli yang masih berlaku sesuai dengan nama di STNK dan BPKB. Syarat tersebut kemudian diserahkan ke ke petugas untuk mengecek kelengkapan persyaratan, lalu regiden akan mencetak SKPD setelah itu STNK akan disahkan, batas waktu untuk pengesahan hanya 30 hari. Di Bali ada dua jenis e-Samsat yang digunakan yaitu e-Samsat Bali dan e-Samsat Nasional, perbedaan dari e-Samsat Bali dan e-Samsat Nasional hanya pada tempat pembayarannya saja.

Menurut Putra selaku wajib pajak, aplikasi e-Samsat ini harus terus dikembangkan karena sangat mudah, cepat dan praktis. E-Samsat ini sangat membantu bagi orang-orang yang jam kerjanya tinggi seperti masyarakat perkotaan yang tidak mempunyai cukup waktu untuk membayar samsat kendaraan.

Menurut Putu Suparta selaku wajib pajak mengungkapkan, aplikasi e-Samsat merupakan inovasi yang sangat bagus, cocok untuk orang-orang yang yang tidak suka mengatri dan orang yang buru-buru untuk membayar Samsat. Membayar samsatnya kan melalui hp jadi dimana saja bisa membayar samsat, tinggal nanti kesini untuk pengesahannya saja. Jadi sangat efektif sekali untuk dikembangkan.

I.G.A Puspita selaku wajib pajak juga mengungkapkan, saya selaku pengguna eSamsat yang baru beberapa bulan menggunakan aplikasi ini sangat mudah, tidak ribet dan tidak perlu lagi mengatre seperti mau nyamsat pada umumnya. Aplikasi ini sangat efektif untuk orang-orang yang sibuk, jadi tidak perlu lagi menyuruh orang lain untuk membantu membayar 
Samsat. Dari aplikasi e-Samsat kita bisa samsat dimana saja dan kapan saja , terus bayarnya bisa dari ATM atau mobile banking jadi ke Samsat hanya untuk pengesaha tidak perlu lagi mengantre lama-lama.

\section{Pajak Progresif}

Sesuai wawancara yang dilakukan dengan I Wayang Agus Bagiarta, S.ST selaku Kasi PKB menjelaskan sesuai dengan Peraturan Daerah Provinsi Bali Nomor 8 Tahun 2016 Perubahan Kedua atas PERDA Provinsi Bali Nomor 1 Tahun 2011, mengenai Pajak Progresif atas pengenaan kendaraan bermotor roda dua, roda tiga, roda empat dan roda dua $250 \mathrm{cc}$ ke atas kepemilikan kedua dan seterusnya yang berdasarkan atas KTP mulai berlaku pada tanggal 3 Oktober 2016. Sebelum adanya perubahan, Pajak Progresif hanya berlaku untuk kendaraan bermotor roda empat untuk kepemilikan kedua dan seterusnya berdasarkan kartu keluarga (KK). Pajak progresif ini hanya dikenakan pada kendaraan bermotor pribadi, sedangkan kendaraan bermotor dinas, badan, lembaga, sosial, konsulat, pemerintah, TNI/POLRI, angkutan umum dan pemadam kebaran tidak dikenakan Pajak Progresif, dan bagi perusahaan yang berskala besar yang memiliki kendaraan pribadi juga tidak dikenakan Pajak Progresif. Pengelompokan pengenaan Pajak Progresif dibagi menjadi lima kelompok kendaraan bermotor, yaitu :

1) Kendaraan bermotor roda 2 (dua) fungsi pribadi di bawah $250 \mathrm{cc}$

2) Kendaraan bermotor roda 2 (dua) fungsi pribadi $250 \mathrm{cc}$ keatas

3) Kendaraan bermotor roda 3 (tiga) fungsi pribadi di bawah $250 \mathrm{cc}$

4) Kendaraan bermotor roda 3 (tiga) fungsi pribadi $250 \mathrm{cc}$ keatas

5) Kendaraan bermotor roda 4 empat atau lebih fungsi pribadi

Tarif pajak kendaraan bermotor roda dua dikenakan sebesar $1,5 \%$, kendaraan bermotor roda tida, roda empat atau lebih dan roda dua diatas $250 \mathrm{cc}$ dikenakan sebasar $1,75 \%$, tarif pajak tersebut merupakan tarif pajak biasa. Tarif Pajak Progresif untuk kendaraan roda dua kepemilikan kedua dikenakan sebsar $2 \%$, sedangkan untuk kendaraan roda tiga, roda empat, dan roda dua diatas $250 \mathrm{cc}$ dikenakan sebesar $3 \%$. Penentuan urutan kepemilikana kendaraan bermotor berdasarkan tanggal kepemilikan kendaraan. Diterapkannya Pajak Progresif yang berlaku pada kendaraan roda dua, roda tiga dan roda dua diatas $250 \mathrm{cc}$, tingkat kepatuhan wajib pajak kendaraan bermotor sedikit menurun namun tidak begitu berarti.

Menurut Putu Suparta selaku wajib pajak berpendapat, dengan diberlakukannya Pajak Progresif ini masyarakat merasa sedikit terbebani dengan jumlah pajak yang harus dibayarkan terutama bagi masyarakat menengah kebawah, namun karena kebutuhan menggunakan kendaraan bermotor sebagai penunjang kegiatan dan merupakan kewajiban membayar pajak jadi kita harus patuh terhadap peraturan yang sudah diterapkan.

Menurut Putra selaku wajib pajak berpendapat, dengan diterapkannya Pajak Progresif merasa agak berat membayar besaran biaya yang harus dibayar, tapi itu sudah peraturan dan pemerintah yang menetapkan jadi harus diikuti dan patuh terhadap kewajiban.

I.G.A Puspita selaku wajib pajak juga berpendapat, penerapan Pajak Progresif tergantung wajib pajaknya masing-masing, Pajak Progresif merupakan pertambahan nilai tarif. Kalau wajib pajaknya menengah keatas mereka tidak akan merasa keberatan dengan dikenakannya Pajak Progresif ini, sebaliknya kalau wajib pajaknya menengah kebawah akan merasa keberatan dengan tarif yang dikenakan. Di zaman sekarang motor merupakan sesuatu yang sangat penting untuk beraktivitas, jadi mau tidak mau mereka harus patuh dan taat terhadap peraturan yang telah ditetapkan.

\section{Kualitas Pelayanan}

I Wayan Agus Bagiarta, S.ST selaku Kasi PKB mengungkapkan bahwa Kualitas pelayanan di UPT. Badan Pendapatan Daerah Provinsi Bali di Kota Denpasar berusaha selalu ditingkatkan sesuai dengan aturan dan SOP dari regulasi, dengan memberikan sikap yang terbaik, pelayanan yang prima untuk meningkatkan kualitas pelayanan. Pihak UPT. Badan Pendapatan Daerah Provinsi Bali di Kota Denpasar juga menyebarkan kuesioner kepada wajib pajak yang bertujuan untuk meningkatkan kualitas pelayanan. Selain itu efisiensi waktu 
juga ditingkatkan agar proses samsat cepat, dan beberapa sarana prasarana dikembangkan agar wajib pajak merasa nyaman saat melalukan kewajibannya.

I Wayan Agus Bagiarta, S.ST juga menjelaskan Untuk mempercepat dan memperlancar pelayanan samsat sarana dan prasarana yang dikembangkan yaitu dengan penambahan komputer untuk mempercepat proses pelayanan. Selain itu SAMSAT pembantu dan gerai-gerai SAMSAT juga dikembangkan untuk meningkatkan kualitas pelayanan dan kenyamanan masyarakat untuk membayar samsat. Perbaikan fasilitas selalu dilakukan secara berkala agar wajib pajak merasa nyaman. Inovasi yang dikembangkan untuk meningkatkan kualitas pelayanan yaitu SAMLING dan Si Kancil. Selain inovasi tersebut pihak UPT. Badan Pendapatan Daerah Provinsi Bali di Kota Denpasar juga melakukan door to door atau terjun langsung ke lapangan untuk menemui wajib pajak yang menunggak, selain itu layanan SAMSAT juga ada pada saat event-event tertentu untuk melayani masyarakat. Sehingga respon dari masyarakat terhadap pelayanan tersebut sangat antusias dan merasa sarana prasarana yang diberikan sangat efektif, nyaman dan cepat.

I.G.A. Puspita selaku wajib pajak berpendapat bahwa Kualitas pelayanan yang baik, cepat dan sigap merupakan sesuatu yang harus selalu ditingkat, masyarakat merasa cepat dan nyaman saat membayar samsat. Jadi masyarakat merasa senang dan puas terhadap pelayanan yang diberikan dan bisa memotivasi untuk kesadaran membayar samsat.

Menurut Putra selaku wajib pajak berpendapat dengan kualitas pelayanan yang baik dan yang memadai tentu masyaraat yang membayar Samsat akan merasa nyaman, terutama dengan pelayanan yang cepat dan tanggap sehingga proses membayar samsat menjadi cepat. Karena masyarakat menyukai pelayanan yang cepat, jadi pelayanan harus selalu ditingkatkan. Sarana dan prasarana juga harus sellau diperbaiki agar masyarakat merasa benar-benar nyaman.

Putu Suparta selaku wajib pajak mengungkapkan sejauh ini sarana dan prasarana yang disediakan cukup memadai, namun fasilitas seperti kursi duduk untuk masyarakat mengatri itu perlu ditambah. Jadi masyarakat yang mengantri dapat duduk biar tidak keliatan menumpuk. Kualitas pelayanan yang diberikan sejauh ini baik responsif, tetapi harus ditingkatkan lagi terutama kecepatan pelayanan harus terus ditingkatkan agar proses samsat menajdi cepat dan nyaman.

\section{Kepatuhan Wajib Pajak Kendaraan Bermotor}

Berdasarkan hasil wawancara bersama I Ketut Dana, S.Sos selaku Bendahara Penerimaan Pembantu UPT. Badan Pendapatan Daerah Provinsi Bali di Kota Denpasar mengungkapkan bahwa: Dengan diterapkannya aplikasi e-Samsat ini kepatuhan wajib pajak kendaraan bermotor dapat meningkat, karena masyarakat atau wajib pajak merasa sangat terbantu dengan aplikasi ini, sedangkan pada penerapan Pajak Progresif sedikit menurun namun tidak begitu berarti. Dengan kualitas pelayanan yang prima, sigap dan tanggap dapat mempengaruhi kepatuhan wajib pajak karena dapat termotivasi untuk membayar pajak kendaraan bermotor.

I Ketut Dana, S.Sos menjelaskan UPT. Badan Pendapatan Daerah Provinsi Bali di Kota Denpasar mengukur tingkat kepatuhan wajib pajak kendaraan bermotor melalui unit kendaraan yang terealisasi per tahunnya. Jumlah unit kendaraan bermotor yang terealisasikan selalu mengalami peningkatan dari tahun ketahun di Kota Denpasar. Pada tahun 2015 jumlah unit yang terealisasikan sebanyak 765,726 unit, pada tahun 2016 sebanyak 747,407 unit, pada tahun 2017 sebanyak 751,682 unit dan pada tahun 2018 dari bulan Januari hingga Oktober unit yang terealisasi sebanyak 623,506 unit. Kepatuhan wajib pajak kendaraan bermotor juga berpengaruh terhadap Pendapatan Asli Daerah khusunya Pendapatan Asli Daerah Kota Denpasar. Pendapatan dari pajak kendaraan bermotor merupakan yang paling tinggi diantara pendapatan pajak daerah lainnya. Dilihat dari laporan Bendahara Pembantu UPT. Badan Pendapatan Daerah Provinsi Bali di Kota Denpasar yaitu pada tahun 2015 pendapatan Pajak Kendaraan Bermotor di Kota Denpasar sebesar Rp $391,284,258,225$,- dari target yang ditentukan sebesar $\mathrm{Rp} 365.000 .000 .000$ pendapatan tersubut meningkat sebanyak 101,54\%. Pada tahun 2016 pendapatan PKB di Kota Denpasar sebesar Rp 431,798,721,260,- dari target yang ditentukan sebesar Rp 406,212,955,989 
pendapatan tersebut meningkat sebanyak 102,98\%. Pada tahun 2017 pendapatan PKB di Kota Denpasar sebesar Rp 529,372,212,262,- dari target yang ditentukan sebesar $R p$ 473,113,914,784,- pendapatan tersebut meningkata sebanyak 106,94\%. Ditahun 2018 hingga Oktober 2018 pendapatan Pajak Kendaraan Bermotor di Kota Denpasar sebesar Rp 451,151,435,850,- dengan target pendapatan sebesar Rp 513,810,428,114,- pemerintah baik dari pihak UPT. Badan Pendapatan Daerah Provinsi Bali di Kota Denpasar terus berupaya agar target Pajak Kendaraan Bermotor pada tahun 2018 dapat tercapai bahkan terlampaui.

\section{Pembahasan E-Samsat}

Sebagai salah satu pengembangan teknologi informasi dan upaya pemerintah dalam meningkatkan kepatuhan wajib pajak kendaraan bermotor diluncurkan aplikasi e-Samsat pada September 2017. E-Samsat merupakan sistem bayar pajak kendaraan bermotor secara online. Dari awal peluncurannya hingga Oktober 2018 jumlah pengguna e-Samsat sebanyak 6.000 pengguna dan diperkirakan akan terus meningkat. Inovasi ini semakin diminati oleh wajib pajak, karena penggunaannya yang sangat mudah, cepat dan praktis serta dapat diakses dimana saja dan kapan saja. Wajib pajak tidak perlu menghitung berapa jumlah pajak yang harus dibayarkan karena dalam pemungutan Pajak Kendaraan Bermotor menggunakan Official Assessment System, dimana sistem pemungutan pajak ini memberikan wewenang kepada pemerintah untuk menentukan besarnya pajak terhutang wajib pajak. E-Samsat merupakan aplikasi yang terbilang masih baru, upaya pemerintah pemerintah untuk mensosialisasikan dan mengembangkan e-Samsat terus dilakukan agar masyarakat lebih tahu dan paham mengenai e-Samsat. Sosialisasi yang dilakukan seperti menyiarkan melalui media penyiaran dan media sosial, mendirikan spanduk, bahkan mensosialisikan langsung ke wajib pajak. Dalam penerapan e-Samsat tentu ada hambatan yang ditemukan dalam penerapannya yaitu masyarakat masih buta dengan teknologi, banyak masyarakat yang masih belum paham menggunakan handphone dan minimnya informasi dan akses mengenai e-Samsat di beberapa wilayah pedesaan, kurang paham mengenai e-Samsat dan tidak melaporkan pajak progresifnya.

Diterapkannya aplikasi e-Samsat ini dapat mempengaruhi kepatuhan wajib pajak kendaraan bermotor, karena dengan inovasi dan kemudahan yang diberikan sangat membantu wajib pajak kendaraan bermotor. Dengan diterapkannya e-Samsat dapat meningkatkan kepatuhan wajib pajak kendaraan bermotor, karena menjadi termotivasi membayar pajak kendaraan bermotor dengan kemudahan yang diberikan. Hal ini berarti persepsi yang disampaikan telah mengacu dengan teori Task Technology Fit (TTF) yang dikembangkan oleh Goodhue dan Thompson (1995) mengemukakan bahwa TTF menjelaskan sejauh mana teknologi membantu individu untuk mengerjakan tugasnya, atau lebih spesifiknya TTF adalah hubungan antara kebutuhan tugas, kemampuan individu dan fungsionalitas teknologi. Teknologi merupakan alat individu untuk menyelesaikan tugas mereka.

\section{Pajak Progresif}

Berdasarkan Peraturan Daerah Provinsi Bali Nomor 8 Tahun 2016 Perubahan Kedua atas PERDA Provinsi Bali Nomor 1 Tahun 2011 Tentang Pajak Daerah mengenai Pajak Progresif yang mulai berlaku per 3 Oktober 2016. Pajak Progresif merupakan pajak pertambahan nilai tarif kendaraan bermotor. Pajak Progresif dikenakan bagi masyarakat atau wajib pajak yang mempunyai kendaraan bermotor baik roda dua, roda tiga, roda empat atau lebih dan roda dua $250 \mathrm{cc}$ keatas yang mempunyai kendaraan lebih dari satu unit. Sebelum PERDA dirubah, Pajak Progresif hanya dikenakan bagi wajib pajak yang mempunyai kendaraan roda empat lebih dari satu unit berdasarkan Kartu Keluarga (KK). Sedangkan setelah perubahan Pajak Progresif dikenakan pada kendaraan roda dua, roda tiga, roda empat dan roda dua diatas 250cc berdasarkan KTP. Penetapan urutan Pajak Progresif berdasarkan tanggal dan bulan pendaftaran kendaraan dan apabila ada perubahan kepemilikan seperti penjualan dan pembelian, wajib pajak harus melaporkan untuk merubah urutan kepemilikan agar kendaraan yang telah dijual bisa diblokir pada sistem. Sedangkan 
untuk kendaraan bermotor dinas, badan, lembaga, sosial, konsulat, pemerintah, TNI/POLRI, angkutan umum dan pemadam kebaran tidak dikenakan Pajak Progresif, dan bagi perusahaan yang berskala besar yang memiliki kendaraan pribadi juga tidak dikenakan Pajak Progresif. Tarif Pajak Progresif untuk kendaraan roda dua dan roda tiga kepemilikan kedua sebesar $2 \%$, dan seterusnya tarif pajak bertambah sebesar 0,5\%. Tarif Pajak Progresif untuk roda dua dan roda tiga $250 \mathrm{cc}$ keatas, dan roda empat kepemilikan kedua dikenakan sebesar $3 \%$, dan bagi kendaraan selanjutnya dikenakan pertambahan tarif $0,5 \%$.

Penerapan Pajak Progresif mempengaruhi kepatuhan wajib pajak kendaraan bermotor. Pajak Progresif merupakan pajak pertambahan nilai tarif kendaraan bermotor sehingga dengan diberlakukannya Pajak Progresif ini masyarakat merasa sedikit terbebani dengan jumlah pajak yang harus dibayarkan terutama bagi masyarakat menengah kebawah, namun karena kebutuhan menggunakan kendaraan bermotor sebagai penunjang kegiatan dan merupakan kewajiban membayar pajak jadi wajib pajak tetap patuh terhadap peraturan yang sudah diterapkan. Berdasarkan penjelasan tersebut persepsi yang disampaikan mengacu pada teori Perpajakan yaitu kontribusi wajib pajak kepada Negara yang terutang oleh orang pribadi atau badan yang bersifat memaksa berdasarkan Undang-Undang, dengan tidak mendapatkan imbalan secara langsung dan digunakan untuk keperluan Negara bagi sebesar-besarnya kemakmuran rakyat.

\section{Kualitas Pelayanan}

Sebagai salah satu kantor pelayanan publik, kualitas pelayanan merupakan sesuatu hal yang sangat penting untuk kelancaran, kenyamanan dan kinerja dari pemerintah tersebut, sehingga menimbulkan rasa senang maupun puas terhadap pelayanan yang diberikan oleh pemerintah. Salah satu cara meningkatkan kepatuhan wajib pajak adalah dengan cara meningkatkan kualitas pelayanan. Pelayanan yang berkualitas terhadap wajib pajak adalah usaha yang dilakukan petugas pajak untuk melayani wajib pajak secara maksimal agar wajib pajak merasa nyaman dan puas terhadap pelayanan yang diberikan. Begitupula yang dilakukan oleh UPT. Badan Pendapatan Daerah Provinsi Bali di Kota Denpasar yang selalu memperbaiki dan meningkatkan kualitas pelayanan. Memberikan kualitas pelayanan yang terbaik dan maksimal agar wajib pajak merasa nyaman saat melakukan kewajibannya. Kesigapan dan kecepatan waktu juga selalu ditingkatkan agar proses samsat bisa cepat. Salah satu upaya yang dilakukan UPT. Dengan kualitas pelayanan yang baik serta sarana dan prasarana memadai, respon masyarakat sangat antusias. Proses pelayanan samsat cepat, lancar dan wajib pajak merasa nyaman dan puas, sehingga dapat meningkatkan kepatuhan wajib pajak kendaraan bermotor di UPT. Badan Pendapatan Daerah Provinsi Bali di Kota Denpasar. Kualitas pelayanan yang baik, cepat, tanggap, dan prima dapat meningkatkan kepatuhan wajib pajak, karena wajib pajak merasa nyaman, cepat dan mudah serta diayomi saat melakukan kewajibannya. Dari pernyataan tersebut mengacu pada teori Teory of Planed Behavioral. Menurut Ajzen (1991) dalam (Anggraini \& Waluyo, 2014), TPB merupakan teori yang menjelaskan bahwa perilaku seseorang sangat dipengaruhi oleh niat dari individu itu sendiri terhadap suatu perilaku (behavioral intention).

\section{Kepatuhan Wajib Pajak Kendaraan Bermotor}

Efektivitas e-Samsat dapat meningkatkan kepatuhan wajib pajak kendaraan bermotor di UPT. Badan Pendapatan Daerah Provinsi Bali di Kota Denpasar, karena wajib pajak dimudahkan dan waktu yang fleksibel dalam membayar pajak kendaraan bermotor sehingga banyak wajib pajak yang manarik untuk menggunakannya. Penggunaan kendaraan bermotor setiap tahunnya mengalami peningkatan yang sanga pesat, sehingga pemerintah berupaya untuk menerapkan Pajak Progresif. Pengenaan Pajak Progresif bagi wajib pajak yang memiliki kendaraan lebih dari 1 unit, dapat mempengaruhi kepatuhan wajib pajak kendaraan bermotor di UPT. Badan Pendapatan Daerah Provinsi Bali di Kota Denpasar. Pajak Progresf merupakan pajak pertambahan nilai tarif kendaraan bermotor, respon masyarakat dengan diberlakukannya peraturan ini merasa terbebani. Diberlakukannya Pajak Progresif minat masyarakat untuk membayar pajak kendaraan menjadi menurun, sehingga berpengaruh kepada kepatuhan wajib pajak kendaraan bermotor di UPT. Badan Pendapatan 
Daerah Provinsi Bali di Kota Denpasar menurun namun tidak begitu berarti. Untuk menunjang e-Samsat dan Pajak Progresif diperlukan pelayanan yang maksimal dari pemerintah. Meningkatkan kualitas pelayanan merupakan sesuatu yang harus selalu ditingkat, perbaikan kualitas pelayanan merupakan salah satu upaya yang harus dilakukan untuk memotivasi dan mendukung niat wajib pajak untuk membayar pajak kendaraan bermotor. Dengan menyediakan pelayanan yang terbaik dan prima, wajib pajak merasa nyaman dan diayomi sehingga dapat meningkatkan kepatuhan wajib pajak kendaraan bermotor di UPT. Badan Pendapatan Daerah Provinsi Bali di Kota Denpasar.

Kepatuhan wajib pajak kendaraan bermotor di UPT. Badan Pendapatan Daerah Provinsi Bali di Kota Denpasar mengukur tingkat kepatuhan wajib pajak kendaraan bermotor melalui unit yang teralisasi setiap tahunnya. UPT. Badan Pendapatan Daerah Provinsi Bali di Kota Denpasar terus mengupayakan agar wajib pajak taat untuk membayar pajak dan unit yang terealisasi tinggi disetiap tahunnya, sehingga Pendapatan Pajak Kendaraan Bermotor di Kota Denpasar selalu dapat terlampaui target yang ditentukan. Pendapatan Pajak Kendaraan Bermotor di Kota Denpasar dari tahun 2015 sampai dengan tahun 2017 mengalami peningkatan yang cukup pesat dan dapat melampaui target yang telah ditentukan sehingga persentase yang dicapai melebihi 100\%. Pada tahun 2018 target penerimaan Pajak Kendaraan Bermotor sebesar Rp 513,810,428,114,-- sedangkan realisasi penerimaan Pajak Kendaraan Bermotor dari bulan Januari hingga Oktober 2018 telah mencapai Rp $451,151,435,850$,- dengan persentase $84,41 \%$, penerimaan tersebut hampir dapat memenuhi target yang ditentukan, ini berarti bahwa tingkat kepatuhan wajib pajak kendaraan bermotor dan kesadaran masyarakat di Kota Denpasar untuk melaksanakan kewajiban tinggi tiap tahunnya. UPT. Badan Pendapatan Daerah Provinsi Bali di Kota Denpasar melakukan segala upaya agar masyarakat sadar dan patuh untuk membayar pajak, karena nantinya dana yang diperoleh akan direalisasikan untuk pembangunan daerah dan untuk kesejahteraan.

\section{SIMPULAN}

\section{Kesimpulan}

Penerapan e-Samsat dan Pajak Progresif serta kualitas pelayanan dapat meningkatkan kepatuhan wajib pajak kendaraan bermotor di UPT Badan Pendapatan Daerah Provinsi Bali di Kota Denpasar. Dengan meningkatnya kepatuhan wajib pajak kendaraan bermotor di Kota Denpasar akan meningkatkan juga pendapatan asli daerah Kota Denpasar, karena Pajak Kendaraan Bermotor merupakan salah satu sumber pajak daerah yang tertinggi. Pada tahun 2018 dari bulan Januari hingga Oktober pendapatan yang diterima sebesar $84,41 \%$ tentu saja persentase tersebut terbilang cukup tinggi, ini berarti bahwa tingkat kepatuhan wajib pajak kendaraan bermotor dan kesadaran masyarakat di Kota Denpasar untuk melaksanakan kewajiban tinggi tiap tahunnya. UPT. Badan Pendapatan Daerah Provinsi Bali di Kota Denpasar melakukan segala upaya agar masyarakat sadar dan patuh untuk membayar pajak, karena nantinya dana yang diperoleh akan direalisasikan untuk pembangunan daerah dan untuk kesejahteraan.

\section{Saran}

a. Diharapkan sistem e-Samsat terus diperbaiki dan diperbarui, seperti dapat melakukan pengesahan STNK dan pencetakan SKPD tanpa wajib pajak datang lagi ke kantor Samsat. Program e-Samsat merupakan inovasi yang sangat efektif untuk memudahkan wajib pajak membayar pajak kendaraan bermotor, agar masyarakat atau wajib pajak sadar dan patuh akan pentingnya melaksanakan kewajiban membayar pajak kendaraan bermotor. Kualitas pelayanan juga harus selalu ditingkatkan dan diperbaiki agar wajib pajak merasa nyaman saat membayar samsat. Sehingga dapat meningkatkan pendapatan asli daerah yang kemudian disalurkan kembali untuk kesejahteraan masyarakat.

b. Bagi peneliti lain diharapkan dapat mendalami lebih dalam dan penelitian lebih lanjut mengenai e-Samsat dan Pajak Progresif ini ataupun pajak daerah lainnya. Atau mungkin bisa meneliti tentang pajak daerah lainnya bukan hanya dilingkup Pajak Kendaraan 
Bermotor saja melainkan pajak daerah lainnya seperti Bea Balik Nama Kendaraan Bermotor, pajak air permukaan, dan lain-lain.

\section{REFERENSI}

Anggraini, F, and Waluyo. 2014. "Faktor Faktor Yang Mempengaruhi Kepatuhan Wajib Pajak Orang Pribadi (Studi Pada Wajib Pajak Orang Pribadi Yang Terdaftar Di KPP Kebayoran Baru Tiga)." Jurnal Akuntansi 1(1): 51-68.

Dharma, G. P. ., \& Alit, K. S. 2014. Pengaruh Kesadaran Wajiib Pajak, Sosialisasi Perpajakan, Kualitas Pelayanan Pada Kepatuhan Wajib Pajak dalam Membayar Pajak Kendaraan Bermotor (PKB) dan pajak Bea Balik Nama Kendaraan Bermotor (BBNKB) pada Kantor Bersama SAMSAT Denpasar. E-Jurnal Akuntansi Universitas Udayana, 6 (1), 340-353.

Ghozali, I. 2013a. Aplikasi Bisnis Multivariative Dengan Program IBM SPSS 21. Semarang: Badan Penerbit Universitas Diponegoro.

Goodhue, Dale L, and Ronald L Thompson. 1995. 19(2) MIS Quarterly Task Technology Fit and Individual Performance.

Ghozali, I. 2013b. Aplikasi Bisnis Multivariative Dengan Program IBM SPSS 23 (8th ed.). Semarang: Badan Penerbit Universitas Diponegoro.

https://www.nusabali.com/berita/30899/wajib-pajak-bisa-memanfaatkan-layanan-e-samsat

Jogiyanto. 2007. Metodologi Penelitian Bisnis: Salah Kaprah dan Pengalaman-pengalaman. Yogyakarta: BPFE.

Kardevi Rakatitha, P. N., \& Gayatri. 2017. PENGARUH KONTRIBUSI PAJAK KENDARAAN BERMOTOR DAN BEA BALIK NAMA KENDARAAN BERMOTOR PADA PENDAPATAN ASLI DAERAH. E-Jurnal Akuntansi Universitas Udayana, 21.2, 1575-1600.

Luh Ayu Gustiari \& Herkulanus Bambang Suprasto. 2018. Sosialisasi Perpajakan Memoderasi Pengaruh Kewajiban Moral dan Kualitas Pelayanan pada Kepatuhan Wajib Pajak Kendaraan Bermotor. E-Jurnal Akuntansi Universitas Udayana, 24.1, 606-632.

Madiasmo. 2013. Perpajakan (Edisi Revi). Yogyakarta: Andi.

Mardiasmo. 2002. Perpajakan. Yogyakarta: Andi.

Mastersite. 2016. Pajak Kendaraan Bermotor. Retrieved from https://forumpajak.org/pajakkendaraan-bermotor/

Pajak Kendaraan Bermotor dan Pajak Mobil Progresif, Bagaimana Cara Perhitungannya? (n.d.). Retrieved from https://www.finansialku.com/pajak-kendaraan-bermotor-danpajak-mobil-progresif-bagaimana-cara-perhitungannya/

Palda, F., \& J. Hanosek. 2002. Journal Quality of Government Services and the Civic Duty to Pay Taxes in the Czech and Slovak Republics, and other Transision Countries.

Peraturan Daerah Provinsi Bali Nomor 1 Tahun 2011 Tentang Pajak Daerah, tersedia di http://ditjenpp.kemenkumham.go.id/files/ld/2011/ProvinsiBali-2011-1.pdf

Peraturan Presiden Republik Indonesia Nomor 5 Tahun 2015, tersedia di http://www.fordamof.org//files/Perpres_Nomor_5_Tahun_2015.pdf

Pradnya Paramartha, I. P. I., \& Rasmini, N. K. 2016. PENGARUH KUALITAS PELAYANAN, PENGETAHUAN DAN SANKSI PERPAJAKAN PADA KEPATUHAN WAJIB PAJAK BADAN. E-Jurnal Akuntansi Universitas Udayana, 15.1, 641-666.

Rhismawati, N. L. 2018. 4.000 wajib pajak di Bali manfaatkan layanan samsat elektronik. Retrieved from https://www.antaranews.com/berita/705897/4000-wajib-pajak-di-balimanfaatkan-layanan-samsat-elektronik

Tresnalyani, N. K. M., \& Jati, I. K. 2018. Pengaruh Kualitas Pelayanan, Pengetahuan Perpajakkan dan Biaya Kepatuhan pada Kepatuhan Wajib Pajak Kendaraan Bermotor. E-Jurnal Akuntansi Universitas Udayana, 24.1, 578-605.

Undang-Undang KUP dan Peraturan Pelaksanaannya, tersedia di http://www.pajak.go.id/sites/default/files/UU-KUP-001-13-UU\%20KUP\%20201300\%20Mobile.pdf

Undang-Undang No. 25 Tahun 2009, Tentang Pelayanan Publik. 
Wirawan, I., \& Burton, R. 2014. Hukum Pajak Teori, Analisis, dan Perkembangannya (Edisi 6). Jakarta: Empat Salemba.

www.jdih.setjen.kemendagri.go.id diakses pada tanggal 10 September 2018 